\title{
1 Genomic regions associated with chocolate spot (Botrytis fabae Sard.) resistance in faba bean (Vicia faba $\mathbf{L}$.
}

2 Tadesse S. Gela ${ }^{1 *}$, Margaret Bruce ${ }^{1}$, Wei Chang ${ }^{2}$, Frederick L. Stoddard ${ }^{3}$, Alan H. Schulman ${ }^{2,4}$, Albert Vandenberg ${ }^{1}$,

3 Hamid Khazaei ${ }^{1,5^{*}}$

$4 \quad{ }^{1}$ Department of Plant Sciences, University of Saskatchewan, Saskatoon, Canada

$5 \quad{ }^{2}$ Institute of Biotechnology and Viikki Plant Science Centre, University of Helsinki, Helsinki, Finland

$6{ }^{3}$ Department of Agricultural Sciences, Viikki Plant Science Centre, and Helsinki Sustainability Science Centre,

7 University of Helsinki, Helsinki, Finland

$8{ }^{4}$ Production Systems, Natural Resources Institute Finland (Luke), Helsinki, Finland

$9{ }^{5}$ World Vegetable Center, Tainan, Taiwan

*E-mail corresponding authors: tadesse.gela@usask.ca; ORCID: 0000-0003-4241-8918

: hamid.khazaei@gmail.com; ORCID: 0000-0002-5202-8764

\section{Key message}

14 QTL mapping identified key genomic regions associated with chocolate spot resistance on faba bean chromosomes 1 and 6, which may serve as novel genetic tools to develop disease-resistant faba bean cultivars.

\section{Abstract}

Chocolate spot (CS), caused by Botrytis fabae Sard., is an important threat to global faba bean production. Growing resistant faba bean cultivars is, therefore, paramount to preventing yield loss. To date, there have been no reported quantitative trait loci (QTLs) associated with CS resistance in faba bean. The objective of this study was to identify genomic regions associated with CS resistance using a recombinant inbred line (RIL) population derived from resistant accession ILB 938. A total of 165 RILs from the cross Mélodie/2 × ILB 938/2 were genotyped and evaluated for CS reactions under replicated controlled climate conditions. QTL analysis identified five loci contributing to CS resistance on faba bean chromosomes 1 and 6 , accounting for $5.0-23.4 \%$ of the total phenotypic variance. The sequences of SNP markers linked to resistance QTLs on chromosome 1 that have the largest effects encode multiple classes of putative disease and/or defense-related genes. The results of this study not only provide insight into disease-resistance QTLs,

27 but also can be used as potential targets for marker-assisted breeding in faba bean genetic improvement for CS 28 resistance. 


\section{Introduction}

32 Faba bean (Vicia faba L., $2 \mathrm{n}=2 \mathrm{x}=12$ ) is a widely grown diploid cool-season legume (pulse) crop with a genome size of approximately $13 \mathrm{~Gb}$ (Soltis et al. 2003). It is the fifth most important pulse crop, after common bean (Phaseolus vulgaris L.), chickpea (Cicer arietinum L.), pea (Pisum sativum L.), and lentil (Lens culinaris Medik.), with an annual production of 5.4 Mt (FAOSTAT 2021). It provides an affordable source of dietary protein, fiber, carbohydrates, and other valuable nutrients (Duc et al. 2015; Khazaei and Vandenberg 2020). The faba bean seed contains about 30\% protein (Warsame et al. 2018), making it one of the best alternative sources for the plant-based protein industry for food, feed, and extractable protein. The crop plays an important role in a sustainable agriculture system, due to its symbiotic fixation of atmospheric nitrogen and its use as a break crop in cereal-dominated rotations (Angus et al. 2015). Global faba bean production is generally challenged by foliar diseases such as ascochyta blight (Ascochyta fabae Speg.), chocolate spot (Botrytis fabae Sard.), rust (Uromyces viciae fabae Pers.), downy mildew (Peronospora viciae (Berk.) Caspary), and gall disease (Physioderma viciae) (Adhikari et al. 2021).

Chocolate spot (CS), caused by the necrotrophic fungal pathogen Botrytis fabae (Sard.), is one of the most destructive diseases of faba bean plants worldwide and can cause up to $90 \%$ yield reduction on susceptible cultivars when conducive environmental conditions prevail (Gorfu and Yaynu 2001; Bouhassan et al. 2004; Tivoli et al. 2006; Beyene et al. 2018). CS can manifest itself on the above-ground parts of the plant at any growth stage, mainly on leaves. It initially appears on leaves as reddish-brown spots that develop into chocolate-colored lesions. These can enlarge into extensive necrotic zones that lead to severe premature defoliation. If the disease develops at flowering time, it can cause complete crop failure. The pathogen survives on crop residues or lodged stubble of the previous year's growing season and on contaminated seeds (Harrison 1988). Its spores are spread primarily between fields by wind and rain.

51 Variation in virulence among B. fabae isolates has been demonstrated (Hutson and Mansfield 1980), although no race 52 classification has been described so far. The strategies used to control chocolate spot on faba bean include crop rotation, reduced planting density, timely fungicide applications, use of clean seeds, and host-plant resistance

54 (Stoddard et al. 2010). Other species of Botrytis contribute to chocolate spot disease, but B. fabae is the main one (Fan 55 et al. 2015).

56 Genetic resistance is a key part of any integrated disease management approach to prevent yield loss caused by CS. 57 Fungal evolution and migration leads to the need for continuous incorporation of new sources of resistance genes or 
58 alleles into elite breeding materials. A few sources of partial genetic resistance to CS have been identified in faba bean germplasm (Hanounik and Robertson 1988; Bouhassan et al. 2004; Villegas-Fernández et al. 2009; Maalouf et al. 2016). Partial resistance to CS was transferred into elite breeding lines and resulted in the release of several cultivars with moderate levels of resistance (Temesgen et al. 2015; Maalouf et al. 2019). Incorporation and pyramiding of CS resistance genes from multiple sources into elite cultivars could be facilitated with marker-assisted selection (MAS). However, the use of MAS in faba bean CS resistance breeding is limited by lack of knowledge of the genetic basis of the resistance so-far identified, by the presence of pathogen variability in the major faba bean diseases (Hanounik and Robertson 1988; Gorfu 1996), and by the lack of adequate genomic resources. faba bean (e.g. Ellwood et al. 2008; Cruz-Izquierdo et al. 2012; Kaur et al. 2014; Webb et al. 2016; Carrillo-Perdomo et al. 2020). Among these maps, the densest SNP-based consensus maps are reported by Webb et al. (2016), constructed from six mapping populations using 687 SNP markers, and Carrillo-Perdomo et al. (2020), a consensus map of three mapping populations consisting of 1,728 SNP markers distributed in six linkage groups. Concurrently, several QTL studies for various faba bean improvement traits have been carried out using different genetic maps (see reviews by O'Sullivan and Angra 2016; Maalouf et al. 2019; Khazaei et al. 2021a) for major foliar diseases such as ascochyta blight (e.g. Avila et al. 2004; Kaur et al. 2014; Atienza et al. 2016; Sudheesh et al. 2019) and rust (e.g. Adhikari et al. 2016; Ijaz et al. 2021). Despite the importance and widespread global nature of CS, no QTL studies have been published to our knowledge. In addition, breeding for CS resistance has been difficult because screening for the disease under field conditions is unreliable, especially in dry environments where faba bean is grown mostly as a rain-fed crop (Adhikari et al. 2021). Humid conditions, which are uncommon in many faba bean-growing areas, provide the opportunity to screen in the field. Identification of reliable molecular markers for use in MAS systems for improving CS resistance is essential for future faba bean breeding. The objective of this study was to identify QTLs associated with CS resistance using an advanced RIL mapping population developed from accession ILB 938 which has partial resistance to CS (Khazaei et al. 2018) under climate-controlled conditions. 


\section{Material and methods}

85

86

87

88

89

90

91

92

93

94

95

96

97

98

99

100

101

102

103

104

105

106

107

108

109

\section{Plant material}

Genetic resistance to B. fabae was evaluated using 165 RILs from the Mélodie/2 × ILB 938/2 cross (Khazaei et al. 2014a). The RILs were advanced using single seed descent to the $F_{8}$ generation. Then the $F_{8}$-derived bulked seeds of the RILs were selfed for at least two additional generations before disease phenotyping. Mélodie/2 was bred at INRA (France) as a source of low vicine-convicine (Khazaei et al. 2014a). ILB 938 (IG 12132) originates from the Andean region of Colombia and Ecuador and has resistance to several biotic and abiotic stresses, including CS (Maalouf et al. 2016; Khazaei et al. 2018). It has high water use efficiency (Link et al. 1999; Khazaei et al. 2014a) and carries a gene that decouples pigmentation in flowers from that in stipules (Khazaei et al. 2014b). It was the first identified source of resistance for CS in faba bean (Hanounik 1982; Khalil et al. 1984; Robertson 1984). ILB 938 resulted from mass selection within ILB 438 (IG 11632). ICARDA's registered BPL (pure line) derivatives of ILB 438 and ILB 938 are BPL 710 and BPL 1179, respectively.

\section{Inoculation and phenotyping for chocolate spot reactions}

A culture stock of B. fabae isolate FB-7 was obtained from the pulse pathology laboratory, University of Saskatchewan for mass spore production. Conidia were cultured on faba bean extract media plates (18 $\mathrm{g}$ of agar, $20 \mathrm{~g}$ of dextrose, $20 \mathrm{~g}$ of $\mathrm{NaCl}$, and $1 \mathrm{~L}$ of faba bean extract which is prepared by boiling $400 \mathrm{~g}$ of faba bean seeds in $1 \mathrm{~L}$ of distilled water for 45 minutes and diluting with $1 \mathrm{~L}$ of distilled water after removing the faba bean seeds) and incubated for 14 $\mathrm{d}$ at room temperature in a cycle of $12 \mathrm{~h}$ of darkness and $12 \mathrm{~h}$ of light to induce sporulation. Plates were then flooded with sterile deionized water and conidia were harvested by scraping the colonies with the edge of a sterile glass microscope slide. The suspension was collected and filtered through one layer of cheesecloth into a clean Erlenmeyer flask. The concentration of the conidial suspension was adjusted to $5 \times 10^{5}$ spores $\mathrm{mL}^{-1}$ using a haemocytometer. The surfactant Tween 20 (polyoxyethylene sorbitan monolaurate) was added at the rate of 1 to 2 drops per $1000 \mathrm{~mL}$ of suspension, and the suspension was shaken well before inoculation.

The parents and 165 RILs were grown in a climate-controlled growth chamber (GR48, Conviron, Winnipeg, Canada) at the University of Saskatchewan's College of Agriculture and Bioresources phytotron facility, Saskatoon, Canada. The growth chamber conditions were adjusted to $18 \mathrm{~h}$ light and $6 \mathrm{~h}$ dark, with the temperatures maintained at $21{ }^{\circ} \mathrm{C}$ 
(day) and $18^{\circ} \mathrm{C}$ (night), and the photosynthetic photon flux density was set to $300 \mu \mathrm{mol} \mathrm{m} \mathrm{m}^{-2} \mathrm{~s}^{-1}$ during the light period

111 at the crop canopy level. Three seeds of each genotype were sown in individual $3.8 \mathrm{~L}$ pots $(15.5 \mathrm{~cm}$ in diameter)

112 containing a soil-less mixture (Sunshine Mix No. 3, Sun Grow Horticulture ${ }^{\circledR}$ Ltd., Vancouver, BC, Canada) and

113 fertilized once per week using $3 \mathrm{~g} \mathrm{~L}^{-1}$ of soluble N:P:K (20:20:20) PlantProd® fertilizer (Nu-Gro Inc., Brantford, ON,

114 Canada). Three weeks after seeding, the plants were inoculated with a spore suspension $\left(5 \times 10^{5}\right.$ spores $\left.\mathrm{mL}^{-1}\right)$ at $\sim 3$

$115 \mathrm{~mL}$ per plant until runoff using a pressurized knapsack sprayer. Plants were placed in an incubation chamber for seven

116 days. Two humidifiers (Vicks Fabrique Paz Canada, Inc., Milton, ON, Canada) were placed in the incubation chamber

117 to ensure $90-100 \%$ relative humidity for infection and disease development. The disease severity data were collected

118 per individual plant at seven days post-inoculation (dpi) using a 0 to 10 rating scale with $10 \%$ increments. The

119 experiment was repeated four times under the same growing conditions during 2020-2021, and each time disease

120 scores were recorded from three replicates (one plant per replicate). Data were converted to percentage disease severity

121 using the class midpoints for data analysis and analyzed as a randomized complete block design.

\section{Statistical analysis}

123 Disease score data were analyzed using SAS v.9.4 (SAS Institute, Cary, USA). Normality and variance homogeneity

124 of the residuals were analysed using the Shapiro-Wilk normality test and Levene's test for homogeneity, respectively.

125 Genotypes were treated as fixed effects and blocks as random effects; significance of variances were declared at 5\%

126 significance level. Least square means were estimated for genotype using LSMEANS statements and used for QTL

127 analysis. Multivariate relationships between RILs and experimental repeats were investigated by principal component

128 analysis (PCA) and biplots of autoscaled (i.e., each repeat mean and grand mean centred at the origin) data in R (R

129 Core Team 2020) with the 'factoextra' package.

\section{Genotyping}

131 Genomic DNA was extracted from three-day-old germinated embryo axes of the parents and 188 RILs from the 132 mapping population using the CTAB method, as described previously (Björnsdotter et al. 2021). DNA quality was 133 assessed by agarose gel electrophoresis; concentrations were determined with a Quant-iT PicoGreen dsDNA Assay 134 Kit (ThermoFisher Scientific, UK) following the manufacturer's guidelines. DNA samples were brought to a 
concentration of $35 \mathrm{ng} / \mu \mathrm{l}$ in $40 \mu \mathrm{l}$ aliquots and genotyped using the Axiom 'Vfaba_v2' 60K array that was developed from metatranscriptome data (O'Sullivan et al. 2019).

\section{Linkage map construction}

Genotypic data for the RIL population was filtered against markers showing significant segregation distortion (deviating from the expected 1:1 ratio) using a chi-square $\left(\chi^{2}\right)$ test. Markers missing in $1 \%$ or more of the data were removed from the analysis. Draft maps were generated from the remaining 180 RILs using ASMap software (Taylor et al. 2017) with a p-value of $1 \mathrm{E}^{-10}$ and a maximum distance between SNP markers of $15.0 \mathrm{cM}$ for grouping them into

142 linkage groups. This linkage map was refined using MapDisto v. 1.7.7.0.1 (Lorieux 2012) with a logarithm of odds

143 (LOD) score of 3.0 and a cut-off recombination value of 0.35 . The best marker order was estimated using both

144 "AutoCheckInversions" and "AutoRipple" commands in MapDisto. Distances between markers were calculated using the Kosambi function (Kosambi 1943). Linkage groups (LGs) were scanned and corrected for double recombinants using MapDisto v. 1.7.7.0.1 (Lorieux 2012). The final LGs were assigned to chromosomes according to the NV644 $\times$

147 NV153 genetic map developed at the University of Reading, UK (unpublished).

\section{QTL mapping of disease resistance}

149 Windows QTL Cartographer 2.5 software (Wang et al. 2012) and multiple QTL mapping (MQM, Manichaikul et al. 150 2009), run in R/qtl software (Broman et al. 2003), were used to detect QTLs. For Windows QTL Cartographer, 151 composite interval mapping (CIM) was implemented using the Kosambi map function with Ril cross type 152 (recombinant inbred line, derived by selfing) at a $1.0 \mathrm{cM}$ interval walk speed. Cofactor selection was performed using 153 forward and backward regression in the standard CIM model with a probability of in and out of 0.1 and a window size 154 of $5 \mathrm{cM}$. QTL significance thresholds were determined by permutation tests (1000 permutations) at a significance 155 level of $P=0.05$. Multiple QTL mapping was completed with the "stepwiseqtl" function (Broman et al. 2003), using 156 the Haley-Knott regression (Haley and Knott 1992) methods. The optimal QTL model was chosen based on the highest 157 penalized LOD score (Manichaikul et al. 2009) after forward and the backward selection and elimination modeling. 158 Penalties for model selection and the genome-wide significance threshold $(=0.05)$ were determined through 1000 159 permutations of the "scantwo" function for two-dimensional QTL scanning. The percentage of the phenotypic 
variance explained (PVE) and effects of QTLs were obtained by fitting a mixed linear model using the "fitqtl" function.

The confidence intervals for each QTL were estimated using the "lodint" function that calculates the 1.5 LOD support intervals. To identify putative candidate genes, the sequences of the SNP markers in the QTL intervals were searched by BLASTn in Phytozome v13 (Goodstein et al. 2012) on the Medicago truncatula reference genome (Mt4.0v1). QTL positions on the linkage map were drawn by MapChart v. 2.2 (Voorrips 2002).

\section{Results}

\section{Phenotypic analysis of the parental lines and RIL population}

Individuals in the RIL population showed significant variation in CS resistance (F-value $=2.21, P=0.0001)$. The parental lines Mélodie/2 and ILB 938/2 exhibited significant differences in resistance to CS under growth chamber conditions (Fig 1). ILB 938/2 had a partial resistant reaction with mean disease severity of 30.4\%, while Mélodie/2 showed a moderately susceptible reaction with a mean of $53.3 \%$. The distribution of disease severity as a measure of

171 CS response for RILs showed continuous variation ranging from $20.8 \%$ to $62.9 \%$, with a mean of $44.5 \%$ (Fig 1), suggesting polygenic regulation of CS severity. Similarly, the autoscaled PCA indicated that the data had no

173 underlying structure for the first two principal components (PC1 vs PC2), which explained approximately $66.1 \%$ of 174 the variance. The PCA-biplot graph also displayed a strong positive correlation among the four screening repeats, which were represented well by the graph (i.e., the vector with equal length), demonstrating that the data could be 176 used for accurate mapping of CS resistance QTLs (Fig 2).

\section{Linkage map construction}

178 A total of 35,363 SNP markers were filtered for polymorphism between the parents, significant segregation distortion,

179 and missing data. A final genetic map was constructed from 4,089 SNP markers, which mapped to six linkage groups

180 (LGs) representing the six chromosomes of faba bean (Table 1). The LGs were numbered to match the respective faba

181 bean consensus map based on where the markers lie (Webb et al. 2016). The linkage map spanned a total genetic 182 distance of $1229.5 \mathrm{cM}$ with an average marker interval of $0.3 \mathrm{cM}$. The genetic distance within LGs varied from 124.2 $183 \mathrm{cM}$ for LG 4 to $396.1 \mathrm{cM}$ for LG 1. LG 4 contained the fewest SNP markers, whereas LG 1 contained the most SNP 184 markers (Table 1; Fig S1). 


\section{QTL analysis}

186 Five QTLs associated with chocolate spot resistance were detected in the RIL population (Table 2 and Figure 3).

187 Among these, two QTLs (qBF1.1 and qBF1.2) were identified on LG 1 by both QTL mapping methods, CIM and

188 MQM, implemented in WinQTLCart and R/qtl software, respectively. The QTL qBF1.1 accounted for 8.9-10.7\% of 189 PVE, whereas qBF1.2 explained 12.2-12.8\% of the PVE (Table 2). These QTLs were derived from the resistant line 190 ILB 938/2. On the other hand, the remaining three QTLs, one on LG 1 (qBF1.3), explained 7.3\% of the PVE, and two 191 on LG 6 (qBF6.1 and qBF6.2), accounted for 6.2 and $6.3 \%$ of the PVE, respectively, were detected solely by CIM 192 methods. The resistance allele for qBF6.1 was contributed by ILB 938/2, whereas the moderately susceptible parent 193 Mélodie/2 was the donor of qBF1.3 and qBF6.2 (Table 2).

\section{Identification of putative candidate genes}

Analysis was conducted of the sequences of the SNP markers in the region of the two stable resistance loci, qBF1.1 and qBF1.2, which were identified by both QTL mapping approaches. A similarity search using BLASTn in the $M$. truncatula genome found a number of potential genes similar to the markers linked to the observed resistance against B. fabae. The sequence of SNP markers linked to qBF1.1 showed similarity with seven genes on chromosome 2 and those linked to qBF1.2 with 16 genes on chromosome 5 of $M$. truncatula, all of which were annotated as genes possibly associated with plant disease resistance and/or defence (Table 3).

\section{Discussion}

Resistance breeding is the most cost-effective and environmentally friendly strategy for controlling CS. Many studies have reported ILB 938 as a source of resistance to CS (e.g. Hanounik and Robertson 1988; Rhaïem et al. 2002; Villegas-Fernández et al. 2009; Maalouf et al. 2016). The introduction of CS resistance from this source into elite 205 cultivars could be accelerated using MAS. To implement MAS in faba bean breeding programs, identification of markers linked to QTLs or genes conferring resistance to CS is the first step. In this study, the analysis of QTLs was conducted using a RIL population derived from ILB 938/2. The RIL population showed significant variation in pathogen response, as expected from the presence of resistance genes or alleles. The frequency distribution of the CS 
$938 / 2$. To our knowledge, this study provides the first identification of genomic regions linked to CS resistance in this species.

212 Here we report the first linkage map, comprised of 4,089 SNP markers in six linkage groups that correspond to the six 213 chromosomes of faba bean, generated for the ILB938-derived RIL population. The genetic linkage map spanned $2141,229.5 \mathrm{cM}$ with an average marker density of $0.3 \mathrm{cM}$. According to Stange et al. (2013), an increase in marker density 215 from 5 to $1 \mathrm{cM}$ could increase the power sufficiently to precisely localize and resolve closely linked QTLs. Therefore, 216 the genetic map developed in this study has sufficient marker density to provide adequate power for QTL mapping.

217 The total map size and the marker distributions along the LGs of the current genetic map are consistent with the 218 consensus map previously published by Webb et al. (2016). It is shorter than the recently published SNP-based consensus map (1547.71 cM) by Carrillo-Perrillo et al. (2020). Like previous marker-based genetic maps (Webb et al. 2016; Carrillo-Perrillo et al. 2020) and cytogenetic studies (Lucretti et al. 1993; Doležel and Lucretti 1995), LG 1, corresponding to chromosome 1, contained the highest number of SNP markers and a larger size. resistance on LG 1 and LG 6. Two QTLs on LG 1 (qBF1.1 and qBF1.2) with high LOD scores were detected by both

224 WinQTLCart and R/qtl. These QTLs were derived from ILB 938/2 and explained a total phenotypic variation of 22\%.

225 The other three QTLs, one on LG 1 (qBF1.3) and two on LG 6 (qBF6.1 and qBF6.2), passed the threshold after permutation and were detected only by WinQTLCart. Interestingly, two of these three QTLs were inherited from the

227 moderately susceptible parent Mélodie/2. In QTL studies for various traits in different crops, the inheritance of the 228 resistance allele from a susceptible parent is not unusual, and a good example is the large effect QTL for improved yield in rice under drought conditions derived from the susceptible parent (Bernier et al. 2007). used as BLASTn queries of the M. truncatula genome, the corresponding regions included several candidate genes that may play a role in disease resistance or defence against biotic stress. Of these, several are promising candidates: an alpha/beta-hydrolase protein, known as the Arabidopsis (Arabidopsis thaliana) Enhanced Disease Susceptibility 1

234 (EDS1) gene (Wittek et al. 2014; Vossa et al. 2019); Bax inhibitor-1 protein (Watanabe and Lam 2006); clathrin adaptor complex protein (Qiao et al. 2010); NAD-dependent epimerase/dehydratase (Islam et al. 2019); 
237 (Janse van Rensburg et al. 2021); F-box protein (Hedtmann et al. 2017); and copper amine oxidase (Rea et al. 2002).

238 All these genes are known to be involved in regulating programmed cell death against pathogens and in controlling

239 cell death proliferation in response to reactive oxygen species (ROS). Recently, Castillejo et al. (2021) reported that

240 resistance to B. fabae is linked to a more efficient photosystem II repair cycle in the resistant faba bean accession BPL

241 710. In response to B. fabae infection, different levels of ROS, lipid peroxidation, and activity of the enzymatic ROS

242 scavenging system were detected in resistant and susceptible faba bean genotypes (El-Komy 2014). However, the

243 antioxidative system is more effective in removing excess ROS produced during infection in the resistant genotype,

244 and pathogenesis-related protein gene transcripts are expressed earlier and higher (El-Komy 2014; Castillejo et al.

245 2021). Genes encoding leucine-rich repeat-containing proteins such as NBS-LRR are typically disease-resistance $(R)$

246 genes that detect the pathogen and activate downstream signaling, leading to pathogen resistance (Dodds and Rathjen

247 2010). We also identified jasmonate ZIM-domain proteins, which are involved in the responses to plant pathogens

248 and abiotic stresses by regulating jasmonic acid signaling pathways and the cross-talk between various phytohormones

249 (Zhou et al. 2015). Furthermore, the expression of genes encoding xyloglucan induces resistance against necrotrophic

250 (B. cinerea) in Arabidopsis (Claverie et al. 2018).

251 Despite the fact that CS is one of the most damaging faba bean diseases worldwide, progress remains slow in breeding

252 for CS resistance. Among the challenges related to faba bean improvement, the restricted appearance of the disease

253 only during the humid climate cropping season makes traditional field-based phenotypic selection unreliable,

254 particularly in dry areas like the Western Canadian prairies and parts of Australia (Adhikari et al. 2021; Khazaei et al.

255 2021b). This might explain why there were no QTL studies of CS previously reported. Therefore, conventional faba

256 bean breeding could be augmented with molecular marker technologies to develop CS-resistant cultivars that are

257 suitable for fulfilling the growing global demand for faba bean generated by its high seed protein content and great

258 ecological service in cropping systems. Our study provides the first QTL identification for CS resistance using high-

259 resolution SNP markers. Some of the identified QTLs in this work can be used as potential targets for further studies,

260 and the linked markers can enable the possibility of using MAS in faba bean CS resistance breeding after validation

261 in appropriate germplasm. 


\section{Acknowledgements}

264 The authors gratefully acknowledge funding from the Danish Innovation Fund for funding the NORFAB project

265 (Innovation Fund Denmark grant number 5158-00004B); ADF (Agriculture Development Fund - Government of

266 Saskatchewan, Canada); the Western Grains Research Foundation, Canada; the Saskatchewan Pulse Growers, Canada;

267 and the Academy of Finland (decision 298314, “Papugeno"). We also thank Dr. Sabine Banniza (Pulse pathology lab,

268 University of Saskatchewan) for technical advice and the staff of the Pulse Crop Breeding Programs for technical

269 support at the University of Saskatchewan.

\section{Author contribution statement}

271 HK, AV, FLS and AHS conceived and designed the experiments. TSG and MB performed the experiments. WC

272 performed DNA extraction and library preparation. TSG and HK analyzed the data. AV, HK, FLS and AHS provided

273 resources and acquired the funding. TSG wrote the first draft of the manuscript. All authors read and reviewed the

274 manuscript.

\section{Conflict of interest}

276 The authors declared that they have no competing interest.

\section{References}

278

279

280

281

282

283

284

285

286

287

288

289

290

291

Adhikari KN, Khazaei H, Ghaouti L, Maalouf F, Vandenberg A, Link W, O'Sullivan DM (2021) Conventional and molecular breeding tools for accelerating genetic gain in faba bean (Vicia faba L.). Front Plant Sci 12:744259.

Adhikari KN, Zhang P, Sadeque A, Hoxha S, Trethowan R (2016) Single independent genes confer resistance to faba bean rust (Uromyces viciae-fabae) in the current Australian cultivar Doza and a central European line Ac1655. Crop Pasture Sci 67:649-654.

Angus JF, Kirkegaard JA, Hunt JR, Ryan MH, Ohlander L, Peoples MB (2015) Break crops and rotations for wheat. Crop Pasture Sci 66:523-552.

Atienza SG, Palomino C, Gutiérrez N, Alfaro CM, Rubiales D, Torres AM, Ávila CM (2016) QTLs for ascochyta blight resistance in faba bean (Vicia faba L.): validation in field and controlled conditions. Crop Pasture Sci 67:216-224.

Avila CM, Satovic Z, Sillero JC, Rubiales D, Moreno MT, Torres AM (2004) Isolate and organ-specific QTLs for ascochyta blight resistance in faba bean. Theor Appl Genet 108:1071-1078.

Bernier J, Kumar A, Ramaiah V, Spaner D, Atlin G (2007) A large-effect QTL for grain yield under reproductivestage drought stress in upland rice. Crop Sci 47:507-516. 
Beyene AT, Derera J, Sibiya J (2018) Genetic variability of faba bean genotypes for chocolate spot (Botrytis fabae) resistance and yield. Euphytica 214:132.

Björnsdotter E, Nadzieja M, Chang W, Escobar-Herrera L, Mancinotti D, Angra D, Xia X, Tacke R, Khazaei H, Crocoll C, Vandenberg A, Link W, Stoddard FL, O'Sullivan DM, Stougaard J, Schulman AH, Andersen SU, Geu-Flores F (2021) VC1 catalyses a key step in the biosynthesis of vicine in faba bean. Nat Plants 7:923931.

Bouhassan A, Sadiki M, Tivoli B (2004) Evaluation of a collection of faba bean (Vicia faba L.) genotypes originating from the Maghreb for resistance to chocolate spot (Botrytis fabae) by assessment in the field and laboratory. Euphytica 135:55-62.

Broman KW, Wu H, Sen S, Churchill GA (2003) R/qtl: QTL mapping in experimental crosses. Bioinformatics 19:889-890.

Carrillo-Perdomo E, Vidal A, Kreplak J, Duborjal H, Leveugle M, Duarte J, Desmetz C, Deulvot C, Raffiot B, Marget P, Tayeh N, Pichon JP, Falque M, Martin OC, Burstin J, Aubert G (2020) Development of new genetic resources for faba bean (Vicia faba L.) breeding through the discovery of gene-based SNP markers and the construction of a high-density consensus map. Sci Rep 10:6790.

Castillejo MA, Villegas-Fernández MA, Hernández-Lao T, Rubiales D (2021) Photosystem II repair cycle in faba bean could play a role in resistance to Botrytis fabae infection. Agronomy 11(11): 224.

Claverie J, Balacey S, Lemaître-Guillier C, Brulé D, Chiltz A, Granet L, Noirot E, Daire X, Darblade B, Héloir MC, Poinssot B (2018) The cell wall-derived Xyloglucan is a new DAMP triggering plant immunity in Vitis vinifera and Arabidopsis thaliana. Front Plant Sci 9:1725.

Cruz-Izquierdo S, Avila CM, Satovic Z, Palomino C, Gutierrez N, Ellwood SR, Phan HTT, Cubero JI, Torres AM (2012) Comparative genomics to bridge Vicia faba with model and closely-related legume species: stability of QTLs for flowering and yield-related traits. Theor Appl Genet 125:1767-1782.

Dodds P, Rathjen J (2010) Plant immunity: towards an integrated view of plant-pathogen interactions. Nat Rev Genet 11:539-548.

Doležel J, Lucretti S (1995) High-resolution flow karyotyping and chromosome sorting in Vicia faba lines with standard and reconstructed karyotypes. Theor Appl Genet 90:797-802.

Duc G, Aleksic JM, Marget P, Mikic A, Paull J, Redden RJ, Sass O, Stoddard FL, Vandenberg A, Vishnyakova M, Torres AM (2015) Faba bean. In: DeRon A (Ed.), Grain Legumes. Handbook of Plant Breeding (Vol. 10, pp. 141-178). Springer, New York, NY, USA.

El-Komy MH (2014) Comparative analysis of defense responses in chocolate spot-resistant and susceptible faba bean (Vicia faba) cultivars following infection by the necrotrophic fungus Botrytis fabae. Plant Pathol J 30:355366.

Ellwood SR, Phan HTT, Jordan M, Hane J, Torres AM, Avila CM, Cruz-Izquierdo S, Oliver RP (2008) Construction of a comparative genetic map in faba bean (Vicia faba L.); conservation of genome structure with Lens culinaris. BMC Genom 9:380.

Fan X, Zhang J, Yang L, Wu M, Chen W, Li G (2015) Development of PCR-based assays for detecting and differentiating three species of Botrytis infecting broad bean. Plant Dis 99(5):691-698.

FAOSTAT (2021) Food and Agriculture Organization of the United Nations. Available online at: http://faostat.fao.org (accessed on October 15, 2021).

Goodstein DM, Shu S, Howson R, Neupane R, Hayes RD, Fazo J, Mitros T, Dirks W, Hellsten U, Putnam N, Rokhsar DS (2012) Phytozome: a comparative platform for green plant genomics. Nucleic Acids Res 40 (D1):D1178D1186. 
Gorfu D (1996) Morphological, cultural and pathogenic variability among nine isolates of Botrytis fabae from Ethiopia. FABIS Newsl 38-39:37-41.

Gorfu D, Yaynu H (2001) Yield loss of crops due to plant diseases in Ethiopia. Pest Manag J Ethiopia 5:55-67.

Haley CS, Knott SA (1992) A simple regression method for mapping quantitative trait loci in line crosses using flanking markers. Heredity 69:315-324.

Hanounik SB (1982) Resistance in faba beans to chocolate spot. FABIS Newsl 5:24-26.

Hanounik SB, Robertson LD (1988) New sources of resistance in Vicia faba to chocolate spot caused by Botrytis fabae. Plant Dis 72:696-698.

Harrison JG (1988) The biology of Botrytis spp. on Vicia beans and chocolate spot disease - a review. Plant Pathol $37: 168-201$.

Hedtmann C, Guo W, Reifschneider E, Heiber I, Hiltscher H, van Buer J, Barsch A, Niehaus K, Rowan B, Lortzing T, Steppuhn A, Baier M (2017) The plant immunity regulating F-Box Protein CPR1 supports plastid function in absence of pathogens. Front Plant Sci 8:1650.

Henry E, Fung N, Liu J, Drakakaki G, Coaker G (2015) Beyon glycolysis: GAPDHs are multi-functional enzymes involved in regulation of ROS, autophagy, and plant immune responses. PLoS Genet 11(4):e1005199.

Hutson, RA, Mansfield JW (1980) A genetical approach to the analysis of mechanisms of pathogenicity in Botrytis/Vicia faba interactions. Physiol Plant Pathol 17:309-317.

Ijaz U, Sudheesh S, Kaur S, Sadeque A, Bariana H, Bansal U, Adhikari K (2021) Mapping of two new rust resistance genes $U v f-2$ and $U v f-3$ in faba bean. Agronomy 11:1370.

Islam R, Brown S, Taheri A, Dumenyo CK (2019) The gene encoding NAD-dependent epimerase/dehydratase, wcaG, affects cell surface properties, virulence, and extracellular enzyme production in the soft rot phytopathogen, Pectobacterium carotovorum. Microorganisms 7(6):172.

Janse van Rensburg HC, Limami AM, Van den Ende W (2021) Spermine and spermidine priming against Botrytis cinerea modulates ROS dynamics and metabolism in Arabidopsis. Biomolecules 11:223.

Kaur S, Kimber RBE, Cogan NOI, Materne M, Forster JW, Paull JG (2014) SNP discovery and high-density genetic mapping in faba bean (Vicia faba L.) permits identification of QTLs for ascochyta blight resistance. Plant Sci 217(218):47-55.

Khalil SA, Nassib AM (1984) Identification of some sources of resistance to disease in faba bean. I. Chocolate spot (Botrytis fabae Sard.). FABIS Newsl 10:18-21.

Khazaei H, O'Sullivan DM, Sillanpää MJ, Stoddard FL (2014a) Use of synteny to identify candidate genes underlying QTL controlling stomatal traits in faba bean (Vicia faba L.). Theor Appl Genet 127:2371-2385.

Khazaei H, O'Sullivan DM, Sillanpää MJ, Stoddard FL (2014b) Genetic analysis reveals a novel locus in Vicia faba decoupling pigmentation in the flower from that in the extra-floral nectaries. Mol Breed 34:1507-1513.

Khazaei H, O'Sullivan DM, Stoddard FL, Adhikari KN, Paull JG, Schulman AH, Andersen SU, Vandenberg A (2021a) Recent advances in faba bean genetic and genomic tools for crop improvement. Legum Sci 3:e75.

Khazaei H, Vandenberg A (2020) Seed mineral composition and protein content of faba beans (Vicia faba L.) with contrasting tannin contents. Agronomy 10:511.

Khazaei H, Link W, Street K, Stoddard FL (2018) ILB 938, a valuable faba bean (Vicia faba L.) accession. Plant Genet Resour 16:478-482.

Khazaei H, Hawkins G, Vandenberg A (2021b) Historical review of faba bean improvement in western Canada. Legum Sci 2021:e92.

Kosambi DD (1943) The estimation of map distances from recombination values. Ann Eugen 12:172-175. 
Link W, Abdelmula AA, Kittlitz EV, Bruns S, Riemer H, Stelling D (1999) Genotypic variation for drought tolerance in Vicia faba. Plant Breed 118:477-484.

Lorieux M (2012) MapDisto: fast and efficient computation of genetic linkage map. Mol Breed 30:1231-1235.

Lucretti S, Doležel, J, Schubert I, Fuchs J (1993) Flow karyotyping and sorting of Vicia faba chromosomes. Theor Appl Genet 85:665-672.

Maalouf F, Ahmed S, Shaaban K, Bassam B, Nawar F, Singh M, Amri A (2016) New faba bean germplasm with multiple resistances to ascochyta blight, chocolate spot and rust diseases. Euphytica 211:157-167.

Maalouf F, Hu J, O'Sullivan DM, Zong Z, Hamwieh A, Kumar S, Baum M (2019) Breeding and genomics status in faba bean (Vicia faba). Plant Breed 138:465-473.

Manichaikul A, Moon JY, Sen S, Yandell BS, Broman KW (2009) A model selection approach for the identification of quantitative trait loci in experimental crosses, allowing epistasis. Genetics 181:1077-1086.

O’Sullivan DM, Angra D (2016) Advances in faba bean genetics and genomics. Front Genet 7:150.

O'Sullivan DM, Angra D, Harvie T, Tagkouli V, Warsame A (2019) A genetic toolbox for Vicia faba improvement. In International conference on legume genetics and genomics, May 13-17, 2019. Dijon, France.

Qiao Y, Jiang W, Lee J, Park B, Choi M, Piao R, Woo M, Roh J, Han L, Paek N, Seo HS, Koh H (2010) SPL28 encodes a clathrin-associated adaptor protein complex 1, medium subunit $\mu 1$ (AP1M1) and is responsible for spotted leaf and early senescence in rice (Oryza sativa). New Phytol 185(1):258-274.

R Core Team (2020) R: A language and environment for statistical computing. R Foundation for Statistical Computing, Vienna, Austria. https://www.R-project.org.

Rea G, Metoui O, Infantino A, Federico R, Angelini R (2002) Copper amine oxidase expression in defense responses to wounding and Ascochyta rabiei invasion. Plant Physiol 128(3):865-875.

Rhaïem A, Cherif M, Kharrat M, Cherif M, Harrabi M (2002) New faba bean genotypes resistant to chocolate spot caused by Botrytis fabae. Phytopathol Mediterr 41:99-108.

Robertson LD (1984) A note on the I.L.B. Source of Botrytis fabae resistance. In: Chapman GP, Tarawali SA (Eds.), Systems for Cytogenetic Analysis in Vicia faba L. Adv Agri Bio. Dordrecht: Springer, vol. 11.

SAS Institute (2015) The SAS System for Windows. Version 9.3. Cary, NC: SAS Institute, Inc.

Soltis DE, Soltis PS, Bennett MD, Leitch IJ (2003) Evolution of genome size in the angiosperms. Am J Bot 90:15961603.

Stange M, Utz HF, Schrag TA, Melchinger AE, Würschum T (2013) High-density genotyping: an overkill for QTL mapping? Lessons learned from a case study in maize and simulations. Theor Appl Genet 126:2563-2574.

Stoddard FL, Nicholas AH, Rubiales D, Thomas J, Villegas-Fernández AM (2010) Integrated pest management in faba bean. Field Crops Res 115:308-318.

Sudheesh S, Kimber RBE, Braich S, Forster JW, Paull JG, Kaur S (2019) Construction of an integrated genetic linkage map and detection of quantitative trait loci for ascochyta blight resistance in faba bean (Vicia faba L.). Euphytica 215:42.

Taylor J, Butler D (2017) R package ASMap: efficient genetic linkage map construction and diagnosis. J Stat Softw 79(6):1-29.

Temesgen T, Keneni G, Sefera T, Jarso M (2015) Yield stability and relationships among stability parameters in faba bean (Vicia faba L.) genotypes. Crop J 3:258-269.

Tivoli B, Baranger A, Avila CM, Banniza S, Barbetti MCW, Davidson J, Lindeck K, Kharrat M, Rubiales D, Sadiki M, Sillero JC, Sweetingham M, Muehlbauer FJ (2006) Screening techniques and sources of resistance to foliar diseases caused by major necrotrophic fungi in grain legumes. Euphytica 147:223-253. 
Villegas-Fernández AM, Sillero JC, Emeran AA, Winkler J, Raffiot B, Tay J, Flores F, Rubiales D (2009) Identification and multi-environment validation of resistance to Botrytis fabae in Vicia faba. Field Crops Res 114:84-90.

Voorrips RE (2002) MapChart: software for the graphical presentation of linkage maps and QTLs. J Hered 93:77-78.

Vossa M, Toelzera C, Bhandari, DD, Parker EJ, Niefind K (2019) Arabidopsis immunity regulator EDS1 in a AD4/SAG101-unbound form is a monomer with an inherently inactive conformation. J Struct Biol 208(3):107390.

Wang S, Basten CJ, Zeng ZB (2012) Windows QTL Cartographer 25. Department of Statistics, North Carolina State University, Raleigh, USA.

Warsame AO, O'Sullivan DM, Tosi P (2018) Seed storage proteins of faba bean (Vicia faba L): Current status and prospects for genetic improvement. J Agric Food Chem 66:12617-12626.

Watanabe N, Lam E (2006) Arabidopsis Bax inhibitor-1 functions as an attenuator of biotic and abiotic types of cell death. The Plant J 45(6):884-94.

Webb A, Cottage A, Wood T, Khamassi K, Hobbs D, Gostkiewicz K, White M, Khazaei H, Ali M, Street D, Duc G, Stoddard FL, Maalouf F, Ogbonnaya FC, Link W, Thomas J, O'Sullivan DM (2016) A SNP-based consensus genetic map for synteny-based trait targeting in faba bean (Vicia faba L.). Plant Biotechnol J 14:177-185.

Wittek F, Hoffmann T, Kanawati B, Bichlmeier M, Knappe C, Wenig M, Schmitt-Kopplin P, Parker JE, Schwab W, Vlot AC (2014) Arabidopsis ENHANCED DISEASE SUSCEPTIBILITY1 promotes systemic acquired resistance via azelaic acid and its precursor 9-oxo nonanoic acid. J Exp Bot 65:5919-5931.

Yang L, McLellan H, Naqvi S, He Q, Boevink PC, Armstrong M, Giuliani LM, Zhang W, Tian Z, Zhan J, Gilroy EM, Birch PRJ (2016) Potato NPH3/RPT2-like protein StNRL1, targeted by a Phytophthora infestans RXLR effector, is a susceptibility factor. Plant Physiol 171(1):645-657.

Zhou X, Yan S, Sun C, Li S, Li J, Xu M, Liu X, Zhang S, Zhao Q, Li Y, Fan Y, Chen, R, Wang L (2015) A Maize Jasmonate Zim-domain protein, ZmJAZ14, associates with the JA, ABA, and GA signaling pathways in transgenic Arabidopsis. PLoS ONE 10(3):e0121824. 
bioRxiv preprint doi: https://doi.org/10.1101/2021.11.22.469473; this version posted November 23, 2021. The copyright holder for this preprint (which was not certified by peer review) is the author/funder, who has granted bioRxiv a license to display the preprint in perpetuity. It is made available under aCC-BY-NC-ND 4.0 International license.

444 Table 1. Characteristics of the genetic linkage map for the 165 faba bean RIL population derived from cross Mélodie/2

$445 \times$ ILB 938/2 at F8.

\begin{tabular}{ccccc}
\hline $\begin{array}{c}\text { Chromosomes } \\
\text { (Linkage groups) }\end{array}$ & $\begin{array}{c}\text { Number of } \\
\text { markers }\end{array}$ & Map length (cM) & $\begin{array}{c}\text { Average marker } \\
\text { interval (cM) }\end{array}$ & $\begin{array}{c}\text { Maximum gap } \\
\text { (cM) }\end{array}$ \\
\hline 1 & 1262 & 396.1 & 0.31 & 3.23 \\
2 & 656 & 218.1 & 0.33 & 3.21 \\
3 & 668 & 181.4 & 0.27 & 3.58 \\
4 & 488 & 124.2 & 0.25 & 2.22 \\
5 & 488 & 139.8 & 0.29 & 4.32 \\
6 & 527 & 169.9 & 0.32 & 3.55 \\
\hline
\end{tabular}


bioRxiv preprint doi: https://doi.org/10.1101/2021.11.22.469473; this version posted November 23, 2021. The copyright holder for this preprint (which was not certified by peer review) is the author/funder, who has granted bioRxiv a license to display the preprint in perpetuity. It is made available under aCC-BY-NC-ND 4.0 International license.

447 Table 2. Quantitative trait loci (QTL) for resistance to chocolate spot in 165 RIL population derived from cross

448 Mélodie/2 × ILB 938/2.

\begin{tabular}{|c|c|c|c|c|c|c|c|c|c|}
\hline \multirow[t]{2}{*}{ QTL } & \multirow[t]{2}{*}{$\mathbf{L G}^{\mathbf{a}}$} & \multirow{2}{*}{$\begin{array}{l}\text { Peak } \\
\text { (cM) }\end{array}$} & \multirow{2}{*}{$\begin{array}{c}\text { 2- LOD } \\
\text { interval (cM) }\end{array}$} & \multicolumn{3}{|c|}{$\operatorname{CIM}^{\mathrm{d}}$} & \multicolumn{3}{|c|}{ MQM $^{\mathbf{d}}$} \\
\hline & & & & LOD & $\mathbf{R}^{\mathrm{b}}(\%)$ & Add $^{\mathbf{c}}$ & LOD & $\mathbf{R}^{\mathrm{b}}(\%)$ & Add $^{\mathrm{C}}$ \\
\hline qBF1.1 & 1 & 28.5 & $22.7-29.7$ & 4.2 & 8.9 & -3.0 & 4.5 & 10.7 & -3.2 \\
\hline qBF1.2 & 1 & 127.3 & $125.2-130.4$ & 5.7 & 12.2 & -3.5 & 5.3 & 12.8 & -3.6 \\
\hline qBF1.3 & 1 & 191.0 & $189.4-192.9$ & 3.5 & 7.3 & 2.8 & - & - & - \\
\hline qFB6.1 & 6 & 109.5 & $104.1-113.2$ & 3.7 & 6.2 & -2.5 & - & - & - \\
\hline qFB6.2 & 6 & 164.0 & $159.9-168.8$ & 3.1 & 6.3 & 4.1 & - & - & - \\
\hline
\end{tabular}

$449 \quad{ }^{\mathrm{a}}$ Linkage group, ${ }^{\mathrm{b}} \mathrm{R}^{2}$ - Percentage of phenotypic variance explained by QTL, ${ }^{\mathrm{c}}$ Additive genetic effect, ${ }^{\mathrm{d}} \mathrm{CIM}$ - composite 450 interval mapping in WinQTLCart and MQM - multiple QTL mapping in R/qtl software 


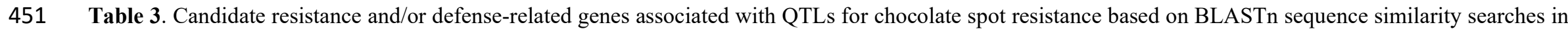

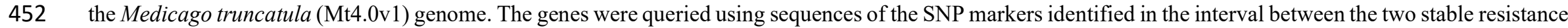
453 loci (qBF1.1 and qBF1.2).

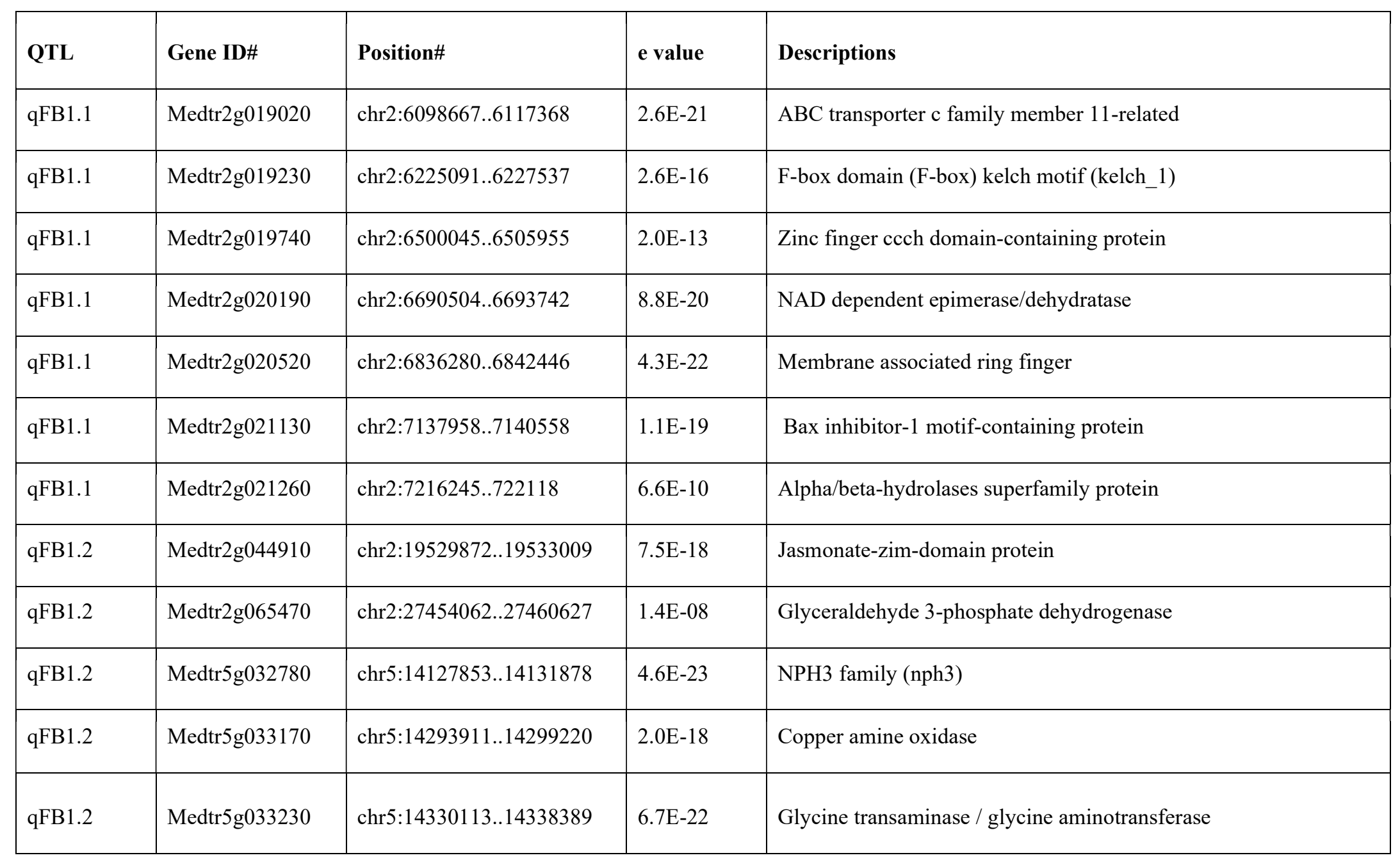




\begin{tabular}{|c|c|c|c|c|}
\hline qFB1.2 & Medtr5g033500 & chr5:14425504..14431918 & $1.4 \mathrm{E}-19$ & $\begin{array}{l}\text { Adaptor complexes medium subunit family (adap_comp_sub) / } \\
\text { clathrin adaptor complex small chain (clat_adaptor_s }\end{array}$ \\
\hline qFB1.2 & Medtr5g033820 & chr5:14595958..14601126 & $2.2 \mathrm{E}-14$ & Pprotein nsp-interacting kinase 3 \\
\hline qFB1.2 & Medtr5g033960 & chr5:14676992..14677753 & $3.2 \mathrm{E}-13$ & Ubiquitin/40s ribosomal protein s27a fusion \\
\hline qFB1.2 & Medtr5g034470 & chr5:14952636..14957856 & $8.5 \mathrm{E}-14$ & Spermine synthase \\
\hline qFB1.2 & Medtr5g035070 & chr5:15256253..15258244 & $3.2 \mathrm{E}-13$ & Protein altered xyloglucan 4 \\
\hline qFB1.2 & Medtr5g035080 & chr5:15260468..15263355 & $5.2 \mathrm{E}-08$ & Protein altered xyloglucan 4 \\
\hline qFB1.2 & Medtr5g035090 & chr5:15265169..15266749 & $1.7 \mathrm{E}-11$ & Protein altered xyloglucan 4 \\
\hline qFB1.2 & $\begin{array}{l}\text { Arath|AT3G14460 } \\
.1 \mathrm{GX} 2357 \mathrm{M}\end{array}$ & chr5:15319859...1532097 & $2.0 \mathrm{E}-04$ & LRR and NB-ARC domains-containing disease resistance protein \\
\hline qFB1.2 & Medtr5g035280 & chr5:15334263..15337184 & $4.2 \mathrm{E}-13$ & Leucine-rich repeat (LRR)-containing protein \\
\hline qFB1.2 & $\begin{array}{l}\text { Arath|AT3G14460 } \\
.1 \_ \text {GX2362M }\end{array}$ & chr5:15345285..15358820 & 7.6E-10 & LRR and NB-ARC domains-containing disease resistance protein \\
\hline qFB1.2 & $\begin{array}{l}\text { Arath|AT3G14470 } \\
.1 \_G X 2447 \mathrm{M}\end{array}$ & chr5:16412520..16415453 & $1.7 \mathrm{E}-05$ & NB-ARC domain-containing disease resistance protein \\
\hline
\end{tabular}


Figure captions:

456 Figure 1. Frequency distributions of chocolate spot disease scores in 165 RILs derived from cross Mélodie/2 $\times$ ILB

$457938 / 2$ evaluated under growth chamber conditions. Each value is the mean of 4 screenings, each with 3 replicates. The

458 arrows indicate the average disease severity of the parents. Disease severity was rated on a 0-10 scale, where the

459 disease severity score increased in $10 \%$ increments

460 Figure 2. PCA-biplot graph of PC1 vs PC2 for auto-scaled and centered data for chocolate spot severity for each

461 repeat (rep) collected from a 165 recombinant inbred lines (RILs) population of a cross Mélodie/2 $\times$ ILB 938/2 cross

462 (FBR-06). Each RIL score, which is a deviation from its rep average value, was displayed as a point on the graph and

463 reps as a blue arrow (vector). The parental lines are circled with black dots. The origin of the graph represents the

464 average value for both each rep and across all repeats. The angle between any two arrows indicates the correlation

465 between repeats (if the angle is 90 degrees, it means both variables show a lack of correlation) and the length of the

466 arrow represents the variance explained by two components (all equal length means a perfect fit). The colour bar

467 indicator on the right shows the deviation of each score from the averages

468 Figure 3. Location of chocolate spot resistance QTLs on chromosome 1 (A, B and C) and 6 (D and E) using 165 RILs

469 derived from cross Mélodie/2 $\times$ ILB 938/2. The QTL positions are shown with a red bar, and the loci within the QTL

470 regions are shown on the right of the bar. Only portions of the linkage map related to the QTL positions are displayed 
bioRxiv preprint doi: https://doi.org/10.1101/2021.11.22.469473; this version posted November 23, 2021. The copyright holder for this preprint (which was not certified by peer review) is the author/funder, who has granted bioRxiv a license to display the preprint in perpetuity. It is made available under aCC-BY-NC-ND 4.0 International license.

471

Fig 1

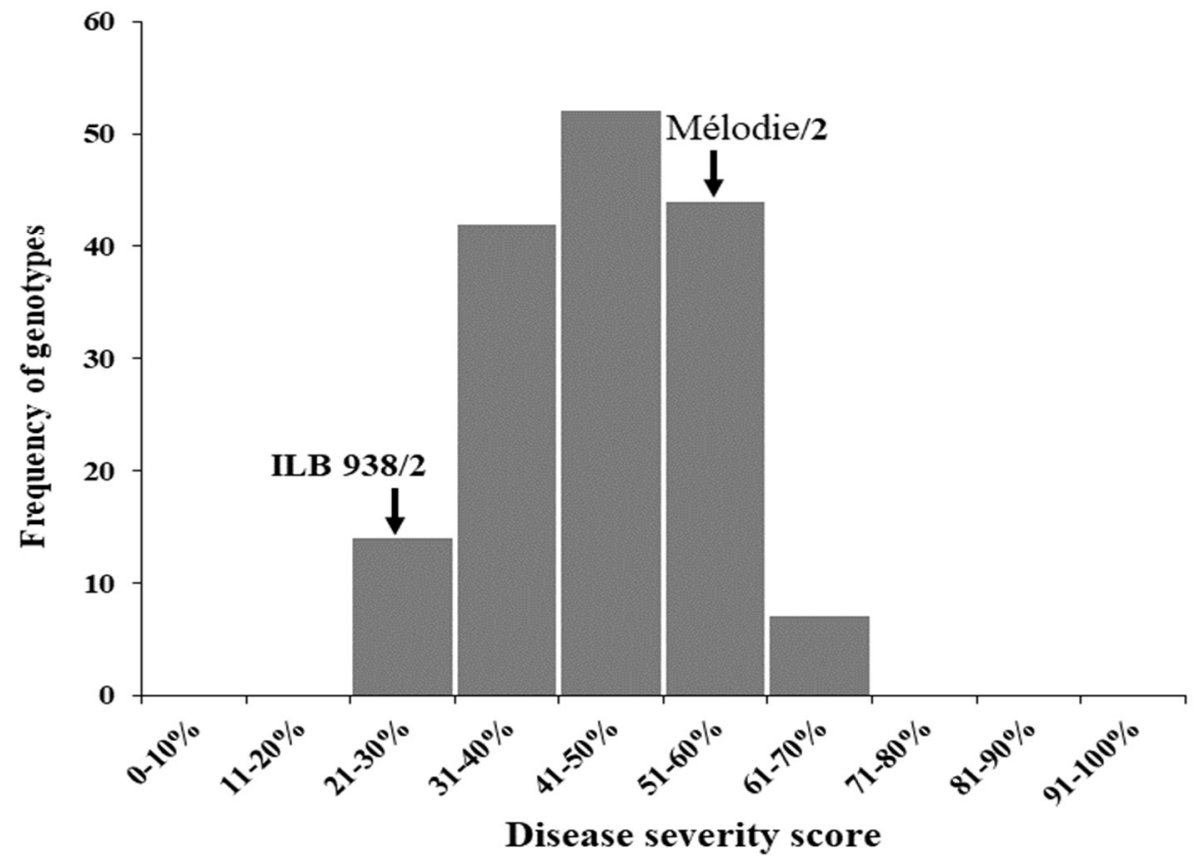

472 


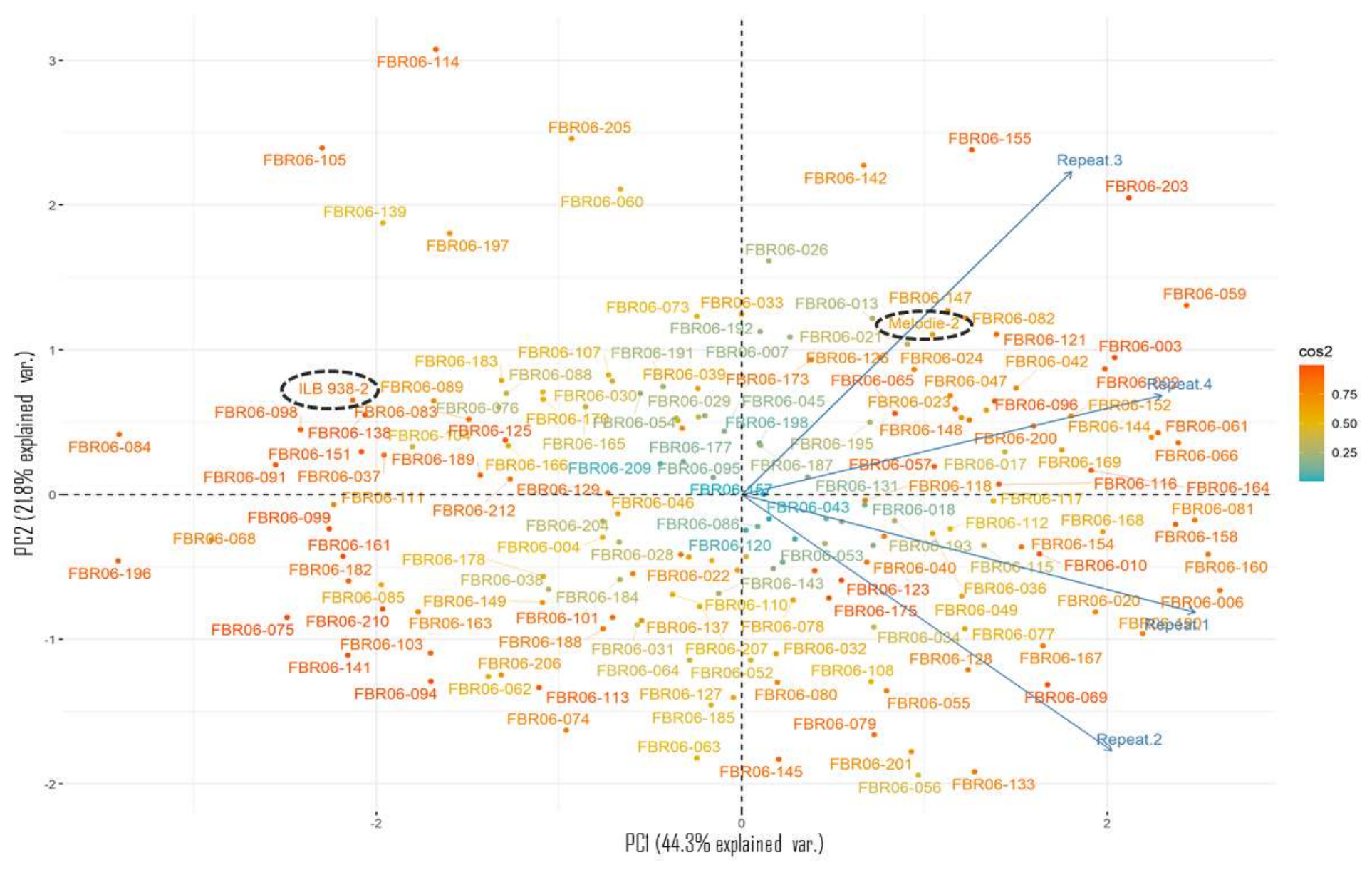


bioRxiv preprint doi: https://doi.org/10.1101/2021.11.22.469473; this version posted November 23, 2021. The copyright holder for this preprint (which was not certified by peer review) is the author/funder, who has granted bioRxiv a license to display the preprint in perpetuity. It is made available under aCC-BY-NC-ND 4.0 International license.

475

Fig 3

A

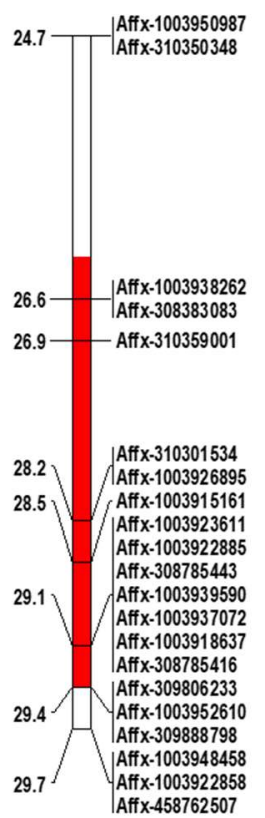

B

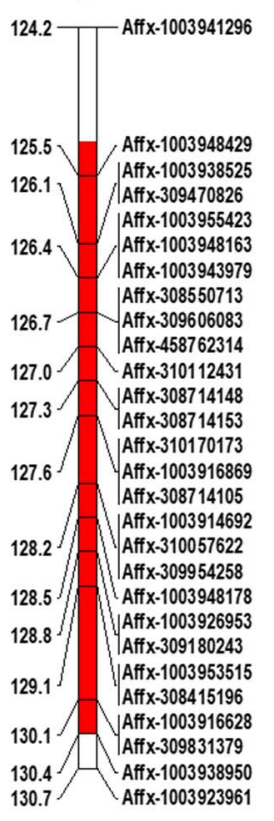

C

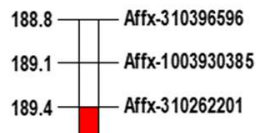

$191.0-\mid \begin{aligned} & \text { Affx-1003938566 } \\ & \text { Affx-310603149 } \\ & \text { Affx-1003951557 }\end{aligned}$

$191.9-$ Affx-310410353

$192.2-$ Affx-1003934072

192.8 — Affx-1003951921

$193.2-\mid \begin{aligned} & \text { Affx-1003951307 } \\ & \text { Affx-1003929349 }\end{aligned}$

$194.1 ـ$ Affx-308814682
D

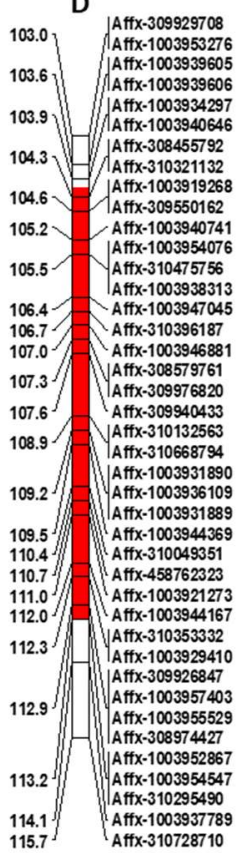

E

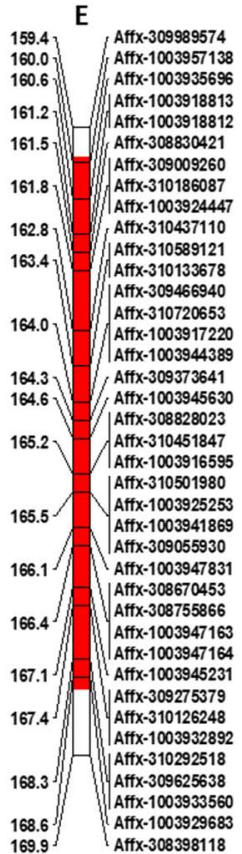


bioRxiv preprint doi: https://doi.org/10 1101/2021.11.22 469473. this version posted November 23, 2021. The copyright holder for this preprint (which was not certified by peer review) is the author/funder, who has granted bioRxiv a license to display the preprint in perpetuity. It is made available under aCC-BY-NC-ND 4.0 International license.

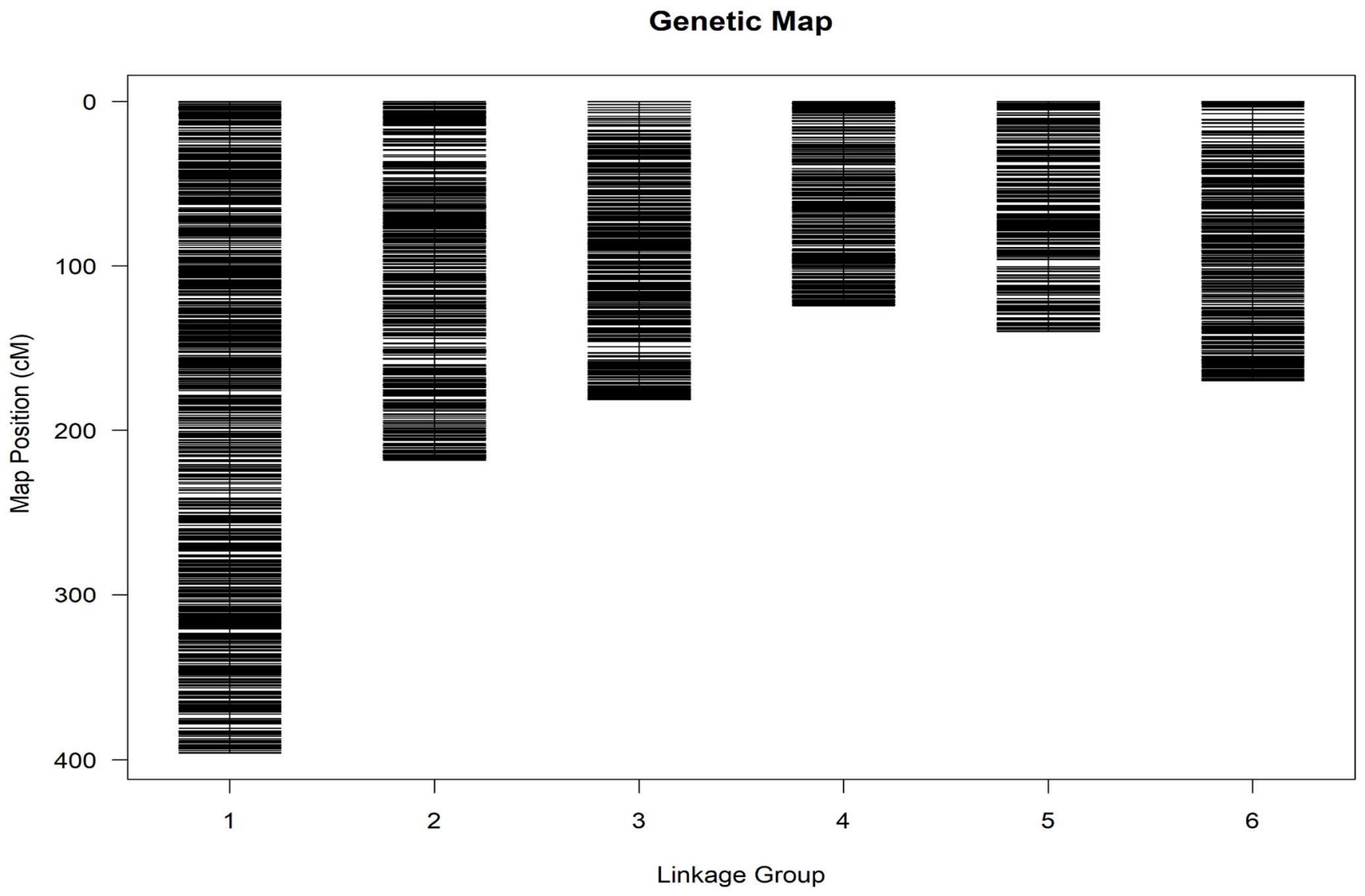

Figure S1. Genetic linkage map of cross Mélodie/2 × ILB 938/2 at F8. 